\title{
The city as a national work of art: modernity and nation building in fin-de-siècle Lviv - CORRIGENDUM
}

\author{
Aleksander Łupienko \\ T. Manteuffel Institute of History, Polish Academy of Sciences, Rynek Starego Miasta 29/31, 00-272 \\ Warsaw, Poland
}

doi: 10.1017/S0963926820000589, published by Cambridge University Press, 7 August 2020.

The original published version of this article did not include details of financial support. The following text has been included in the online PDF and HTML copies:

Financial support. This article is a result of research into the functioning of urban architecture in the Polish territories (1850-1914) and financed from funds from the National Science Centre in Poland.

\section{Reference}

Lupienko, A. (2020). The city as a national work of art: modernity and nation building in fin-de-siècle Lviv. Urban History, 1-21. doi:10.1017/S0963926820000589

Cite this article: Eupienko A (2021). The city as a national work of art: modernity and nation building in fin-de-siècle Lviv - CORRIGENDUM. Urban History 48, 684-684. https://doi.org/10.1017/ S0963926820001054

(C) The Author(s), 2021. Published by Cambridge University Press. This is an Open Access article, distributed under the terms of the Creative Commons Attribution-NonCommercial-NoDerivatives licence (http://creativecommons.org/ licenses/by-nc-nd/4.0/), which permits non-commercial re-use, distribution, and reproduction in any medium, provided the original work is unaltered and is properly cited. The written permission of Cambridge University Press must be obtained for commercial re-use or in order to create a derivative work. 